\title{
Starting out as a physician-scientist: the crucial first step on the ladder to success
}

\author{
Joseph L. Goldstein \\ Regental Professor and Chair, Department of Molecular Cenetics, University of Texas Southwestern Medical Center, Dallas, Texas, USA.
}

M

any of you in the audience are just beginning your careers as physician-scientists. And most of you, I suspect, are struggling with the question of how can I do something worthwhile in biomedical research. The answer to your struggles may be found in a provocative sculpture created by the contemporary African American artist Martin Puryear (Figure 1).

Puryear's sculpture is a tall wooden ladder (36 feet high) suspended by invisible wires, enabling it to float from the ceiling of the atrium of the Museum of Modern Art in Fort Worth. Puryear constructed the ladder from a single oak tree. The bottom rung is 2 feet wide, and the top rung is 1 inch wide. There are 100 rungs, most of which are at the top and not visible in the photograph. The narrowing of the ladder towards the top creates a distorted visual perspective that evokes an illusionary goal that is unattainable. It is easy to get both feet on the first rung of the ladder, but it is an almost impossible struggle to reach the top. Opportunity narrows at the very highest reaches.

Puryear created this work to symbolize the struggles of Booker T. Washington, who was the dominant African American figure in the U.S. in the early 1900s. Booker T. Washington was born into slavery in 1856 , was freed at age 9 , and by age 25 had established the Tuskegee Institute in Alabama as a trade school for African Americans. His autobiography, Up from Slavery, is still read today, more than 100 years after it was written. Harvard University conferred an honorary degree on Washington in 1896 when he was only 40 years of age.

Puryear's ladder can be thought of as a universal metaphor for everyone who struggles to do something worthwhile. But there's another way to think about the ladder that may be more relevant to beginning physician-scientists (Figure 2). If we turn the Booker T. Washington ladder upside down, the difficult challenge is not at the top, but at the bottom - getting your little toe on the first rung. Here the ladder symbolizes the struggles of physician-scientists like Barry J. Marshall, who made the totally unexpected discovery that peptic ulcers are caused not by stress, but by a bacterial Helicobacter infection that can be cured with antibiotics. Marshall got his first toe on the ladder by doing a bold experiment in 1985 that opened a new field, but virtually no one recognized the significance of his work when it was first published in the Medical Journal of Australia - not one of your high-profile journals!

The Barry J. Marshalls of the world who do truly original research have the first 94 rungs of the upside-down ladder all to themselves for many years until reaching the 95th rung - the 5th

Reference information: / Clin Invest. 2017;127(10):3576.

https://doi.org/10.1172/JCI97405.

Remarks at the Presentation of the 2017 Donald Seldin Holly Smith Award for Pioneering Research during the annual meeting of the American Society for Clinical Investigation and Association of American Physicians, Chicago, IL, April 22, 2017.

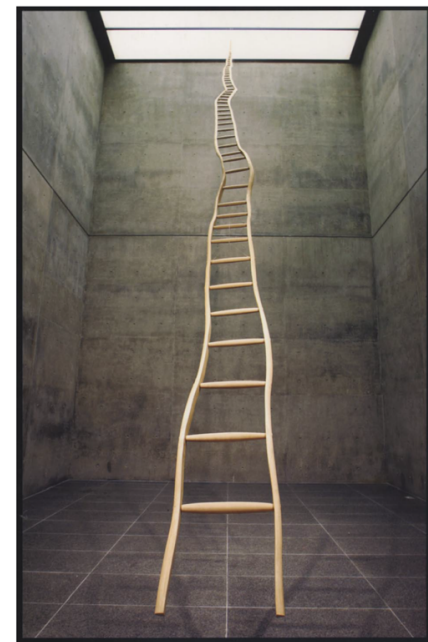

Figure 1. Ladder for Booker T. Washington. Martin Puryear. 1966. Wood (ash and maple). $36 \times 1.9$ feet (narrowing at top to 3 inches). Collection of the Modern Art Museum of Fort Worth. Gift of Ruth Carter Stevenson, by Exchange.

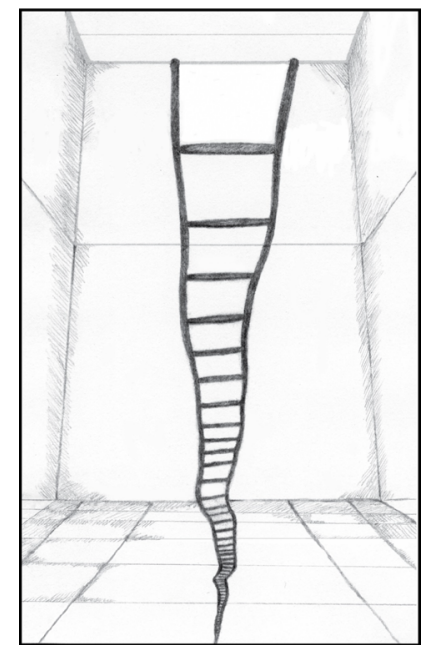

Figure 2. Ladder for physicianscientists. Puryear's Ladder has been turned upside down. Illustration by Nancy Heard; reproduced with permission of the artist. rung from the top - where there's now room for other scientists to jump on the bandwagon and join in on the fun and excitement of a new venture. This is the tipping point when a new field of science or medicine explodes with widening opportunities and becomes widely recognized as important.

So what is the best way for a young physician-scientist to get his or her little toe on the first rung of the upside-down ladder? The key is to choose the right mentor. You don't want a mentor who counts papers, who is focused on impact, or who seeks press conferences. What you want is a mentor who can teach you how to ask the right question. Asking and framing the right question one that is original, interesting, and experimentally tractable - is the hardest thing to do in science. In my view, the biggest mistake that beginning scientists make is to follow the crowd, which means you will be asking the next incremental question - not a bold one.

To the beginning physician-scientists in the audience, I wish you all good luck and success in selecting a mentor who can teach you how to ask the right question. Remember, you can't choose your parents, but you can choose your mentors.

Address correspondence to: Joseph L. Goldstein, Department of Molecular Genetics, University of Texas Southwestern Medical Center, 5323 Harry Hines Blvd., Room L5-238, Dallas, Texas 75390-9046, USA. Phone: 214.648.2141; Email: joe.goldstein@ utsouthwestern.edu. 